\title{
OVEREXPRESSION OF HER2/NEU ONCOGEN, P53 AND ESTROGEN RECEPTOR IN ENDOMETRIAL HYPERPLASIA AND CARCINOMA
}

\author{
ZiHel H. Hussein and Bashar A. Hassawi \\ Dept. of Anatomy. College of medicine. University of Duhok, Kurdistan Region-Iraq
}

(Received: February 8, 2019; Accepted for Publication: May 7, 2019)

\begin{abstract}
Background: Endometrial hyperplasia with its two types (simple and complex hyperplasia with or without atypia) is one of the most important endometrial lesions. The probability of progression of endometrial hyperplasia to carcinoma is related to the degree of architectural and/or cytological atypia. There are two fundamentally different pathogenic types of endometrial carcinoma: type I (estrogen related, endometrioid type) and type II (non-estrogen related, non-endometrioid type). Recently, various biomarkers detect prognostic factors in endometrial carcinomas, such as Her2/neu, P53 as well as Estrogen Receptor (ER).

Materials and Methods: During the period from November 2015 to May 2016, 101cases (as blocks) were collected from the archive of different Laboratories. There were 52 cases of endometrial hyperplasia; the other 49 cases were endometrial carcinoma. All the cases were revised histologically (using Hematoxylin and Eosin stain) to identify the types of hyperplasia and carcinoma, as well as the grade of carcinoma and the degree of myometrial invasion. Three markers were applied (Her2/neu, P53 and Estrogen Receptor) by using automated immunohistochemistry staining.

Results: The predominant cases of the endometrial hyperplasia were in the $5^{\text {th }}$ decade with a mean age (44.6) years. The majority were simple hyperplasia without atypia. The endometrial carcinoma cases were predominant in the $6^{\text {th }}$ decade with a mean age (55.5) years. The majorities were of the classical type $(65.3 \%)$ and grade II (48.9\%). Her $2 /$ neu expression significantly increased in positivity ( $p=0.001$ ), while $P 53$ did not show significant changes with disease progression $(p=0.1)$. Estrogen Receptor immunoreactivity was decreased significantly from simple hyperplasia to carcinoma $(p=0.001)$. There were no correlation between these triple markers and increasing grade. Although, the number of cases showed more positivity of Her $2 /$ neu and P53 with the increasing of myometrial invasion and expression of Estrogen receptor decreased but the relation was statistically not significant $(p=0.9)$. Among the studied cases, there were $18.2 \%$ and $50 \%$ of complex hyperplasia without atypia and atypical hyperplasia respectively transmitted to carcinoma, while none of the simple hyperplasia cases showed transmission to carcinoma.

Conclusions: Cases of the endometrial hyperplasia were more prevalent at pre and perimenopausal period while endometrial carcinoma was more prevalent in postmenopausal women. Her2/neu showed more immunoreactivity with progression of the pathological change (increasing morphological and cytological complexity) from endometrial hyperplasia to carcinoma in contrast to Estrogen Receptor expression which showed converse relationship with progression of the disease. Expression of P53 was seen to have more immunoreactivity with high grade and highly invasive tumor.
\end{abstract}

KEY WORDS: Uterus, Endometrium, Hyperplasia and carcinoma.

\section{BACKGROUND}

$\mathbf{E}$ ndometrium is the inner lining tissue of the uterus and it is exposed to hormonal effects during normal menstrual cycle. This exposure stimulates the glands and stroma. Abnormal changes in hormonal level may induce pathological transformation which is varying from simple abnormal bleeding to neoplastic proliferation; these include endometrial hyperplasia and carcinoma (Kumar et al., 2003).
They are typically diagnosed by endometrial biopsy or endometrial curettage after the woman presents to the gynecologist with abnormal uterine bleeding. (Lacey et al., 2007) .

Endometrial carcinoma is the sixth most frequent. Endometrial carcinoma is classified into two different types. Type I tumors (80\%-90\%), endometrioid carcinomas, are often preceded by endometrial hyperplasia and associated with estrogenic stimulation. Typically, follow a favorable course. In contrast, type II tumors (10\%- 
20\%) are non-endometrioid, arising occasionally in endometrial polyps or from precancerous lesions in atrophic endometrium (endometrial intraepithelial carcinoma) (Galic et al., 2014). Type II tumors are not associated with estrogen stimulation or hyperplasia, readily invade myometrium and vascular spaces, and are highly lethal (Catasús et al., 2009).

Her2/neu is a proto-oncogene, amplification or overexpression of this oncogene has been shown to play an important role in the development and progression of many types of endometrial cancer (Mariani et al., 2005).

P53 is a tumor suppressor protein that is in humans encoded by the TP53 gene; it regulates the cell cycle and thus, functions as a tumor suppressor that is involved in preventing cancer (Okuda et al., 2010). The P53 gene is often found to be genetically altered in tumors, and is one of the most frequently inactivated genes in human cancers (Vogelstein et al., 2000).

Estrogen is an important sex hormone produced primarily in the ovaries in females and testes in males; biologically it is important in the development and function of numerous tissues and physiological phenomena (Al-Bader et al., 2011). ERs belong to the steroid hormone superfamily of nuclear receptors (NRs) that are response to estrogen hormone (Osz et al., 2012).

\section{MATERIALS AND METHODS}

During the period of the study from November 2015 to May 2016, 101 cases (as blocks) were collected from the archive of different Laboratories. The selected blocks were from January 2012 to January 2016. There were 52 cases of endometrial hyperplasia (42 biopsies were obtained by dilatation and curettage and 10 biopsies obtained by total abdominal hysterectomy and bilateral salpingo-oopherectomy). The other 49 cases were endometrial carcinoma (All the biopsies were obtained by total abdominal hysterectomy and bilateral salpingooopherectomy). All the cases were revised histologically (using Hematoxylin and Eosin stain) to identify the types of hyperplasia and carcinoma, as well as the grade of carcinoma and the degree of myometrial invasion. Three markers were applied (Her2/neu, P53 and Estrogen Receptor) by using automated immunohistochemistry staining.

\section{Subject and Study Design}

A cross-sectional study was carried out during the period from November 2015 to May 2016. 101 cases (as blocks) were collected from the archive of different Laboratories in Duhok city. The selected blocks were from the period of January 2012 to January 2016. There were 52 cases of endometrial hyperplasia (42 biopsies were obtained by dilatation and curettage and 10 biopsies obtained by total abdominal hysterectomy and bilateral salpingo-oophorectomy). The other 49 cases were endometrial carcinoma (All the biopsies were obtained by total abdominal hysterectomy and bilateral salpingooophorectomy). The information of patients was obtained from laboratory archive on age, clinical presentation, history of disease and type of the operation (curettage or hysterectomy).

\section{RESULTS}

Figure 1 and2 show the age distribution of endometrial hyperplasia and carcinoma. In hyperplasia cases the peak distribution was seen in age interval (41-50 years) while among the carcinoma cases the most common age group were in age interval (51-60 years). 


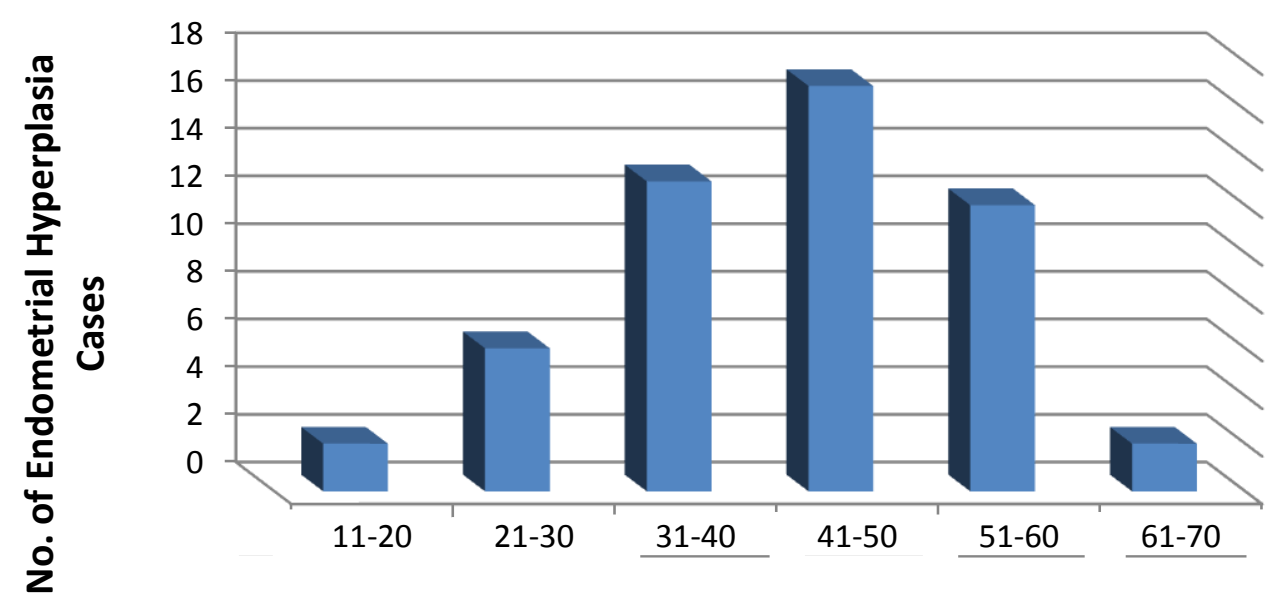

Age interval (Years)

Fig (1): Age Distribution of Endometrial hyperplasia

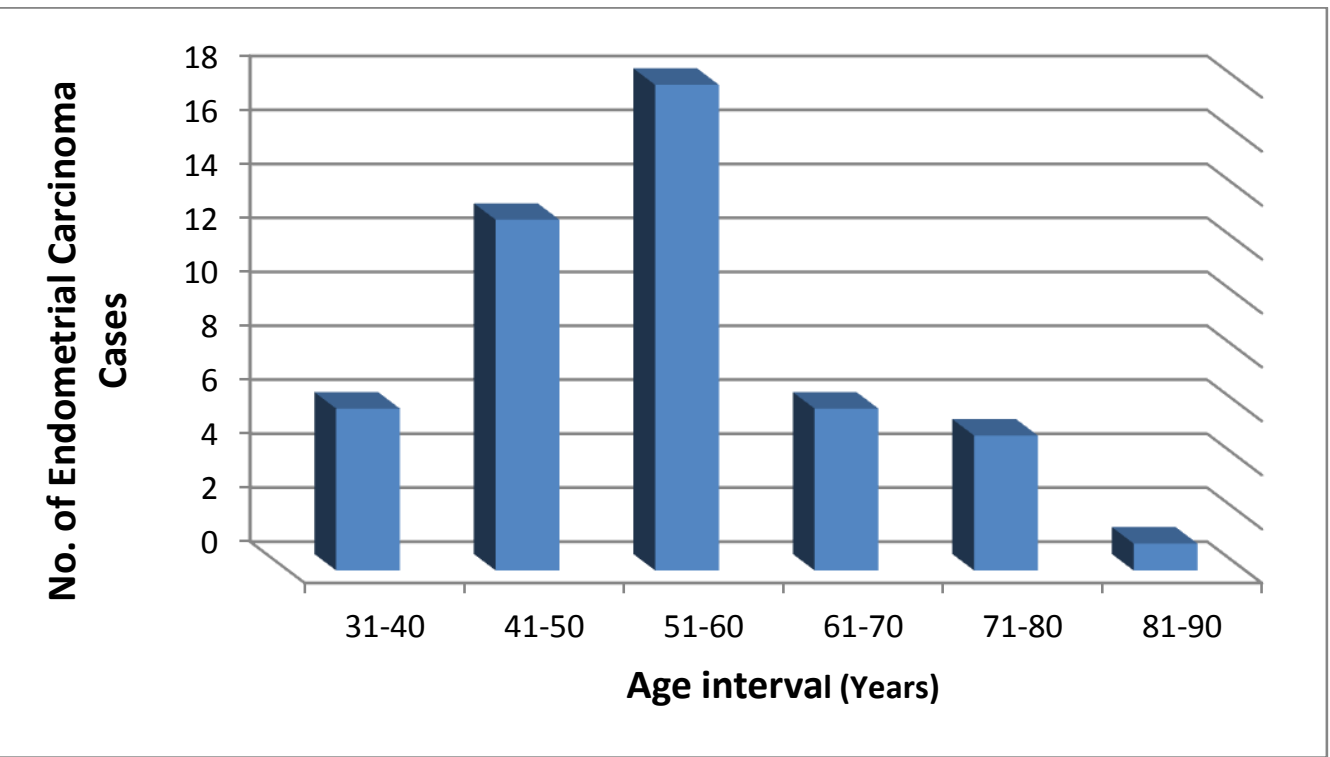

Fig (2): Age Distribution of Endometrial carcinoma

Table 1 shows the relationship between mean age and types of hyperplasia as well as carcinoma. The $\mathrm{p}$ value 0.001 was statistically significant which mean the old ages are more susceptible to atypical hyperplasia and to carcinoma than the younger.

Table (1): Relationship between mean age and types of hyperplasia and carcinoma

\begin{tabular}{lcccccc}
\hline & Pathological Changes & No. & $\%$ & Mean age & SD & P value \\
\hline \multirow{3}{*}{$\begin{array}{l}\text { Endometrial } \\
\text { hyperplasia }\end{array}$} & Simple & 33 & 63.5 & 42.2 & 10.01 \\
\cline { 2 - 6 } & Complex & 11 & 21.1 & 43.8 & 13.3 & 0.001 \\
\cline { 2 - 6 } & Atypical & 8 & 15.4 & 55.2 & 6.96 \\
\hline Carcinoma & & 49 & 100 & 55.5 & 12.9 \\
\hline
\end{tabular}


As shown in Figure 3 the majority of the cases are T1a with no myometrial invasion in 33 cases (67.3\%) while the least cases were T2-T3 (18.4\%) the invasion reach outside of the myometrium (Figure 4-6). And Table 3 shows the distribution of the grades of carcinoma: in this study Grade I was the most found in 21 cases $(42.9 \%)$, and the least number was found in grade III in 4 cases $(8.2 \%)$.

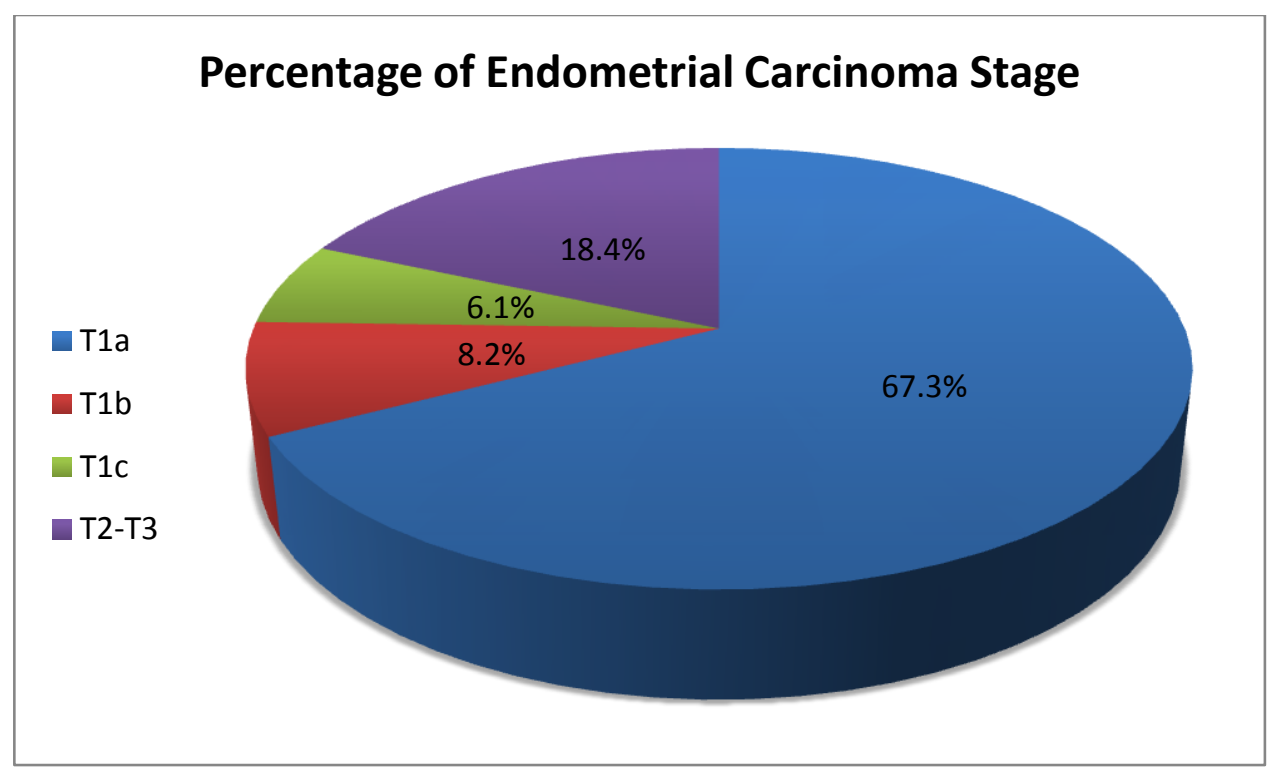

Fig (3): Staging of Endometrial Carcinoma ( $\mathrm{T}=$ According to Myometrial Invasion)

Table 2 shows three grades of carcinoma I, II and III and their mean age distribution. The $\mathrm{p}$ value 0.04 was statistically significant which mean grade of endometrial become poorly differentiated in older age.

Table (2): The Relationship between Mean Age and Grade of Carcinoma

\begin{tabular}{cccccc}
\hline Grade & No & $\%$ & Mean age & SD & $P$ value \\
\hline I & 21 & 42.9 & 51.8 & 10.9 & 0.04 \\
\hline II & 24 & 48.9 & 56.6 & 13.3 \\
\hline III & 4 & 8.2 & 68.7 & 13.1 \\
\hline Total & 49 & $\mathbf{1 0 0}$ & $\mathbf{5 5 . 5}$ & $\mathbf{1 2 . 9}$ \\
\hline
\end{tabular}

Table 3 shows the immunoreactivity of the Her2/neu in both endometrial hyperplasia and carcinoma cases. In this study, among the simple hyperplasia, only 3 cases $(9.1 \%)$ were showed positive immunoreactivity. The complex group 7 cases $(63.6 \%)$ were positive. The atypical hyperplasia showed higher immnuoreactivity $4 / 8$ cases $(50.0 \%)$. While in the carcinoma group (49 cases) 22 cases gave positivity (44.9\%). The $\mathrm{p}$ value 0.001 is statistically significant which means positivity increased when the case progress from simple without atypia hyperplasia towards carcinoma. 
Table (3): Her2/neu Expression in Endometrial Hyperplasia and Carcinoma

\begin{tabular}{|c|c|c|c|c|c|c|}
\hline \multirow{2}{*}{\multicolumn{2}{|c|}{ Pathological Changes }} & \multirow{2}{*}{$\begin{array}{c}\text { Her-2/neu } \\
\text { Positive No. }\end{array}$} & \multirow{2}{*}{$\begin{array}{c}\text { Her-2/neu } \\
\text { Negative No. }\end{array}$} & \multirow{3}{*}{$\begin{array}{c}\text { Total No. } \\
33 \\
\end{array}$} & \multirow{3}{*}{$\begin{array}{c}\% \text { of Positive cases } \\
(9.1) \\
\end{array}$} & \multirow[t]{3}{*}{$P$-Value } \\
\hline & & & & & & \\
\hline Endometrial & Simple & 3 & 30 & & & \\
\hline \multirow[t]{2}{*}{ hyperplasia } & Complex & 7 & 4 & 11 & $(63.6)$ & \multirow[t]{3}{*}{0.001} \\
\hline & Atypical & 4 & 4 & 8 & $(50.0)$ & \\
\hline Carcinoma & & 22 & 27 & 49 & $(44.9)$ & \\
\hline \multicolumn{2}{|c|}{$\begin{array}{c}\text { Total cases of hyperplasia and } \\
\text { carcinoma }\end{array}$} & 36 & 65 & 101 & 35.6 & \\
\hline
\end{tabular}

Table 4 clarified the distribution of Her2/neu expression in endometrial carcinoma according to the grade shown in table 6: The p value is 0.2 and statistically is not significant which reveals that the degree of positivity is not changed from grade I to grade III in endometrial carcinoma.

Table (4): Her2/neu Expression in Grades of Endometrial Carcinoma

\begin{tabular}{cccccc}
\hline $\begin{array}{c}\text { Grade of } \\
\text { carcinoma }\end{array}$ & $\begin{array}{c}\text { Her-2/neu } \\
\text { Positive }\end{array}$ & Her-2/neu Negative & Total & \% of Positive cases & P-Value \\
\hline Grade I & 7 & 14 & 21 & $(33.3)$ & 0.2 \\
\hline Grade II & 12 & 12 & 24 & $(50.0)$ & $(75.0)$ \\
\hline Grade III & 3 & 1 & 4 & 44.9 & \\
\hline Total & 22 & 27 & 49 & & \\
\hline
\end{tabular}

Table 5 shows P53 expression in endometrial hyperplasia and carcinoma. The expression of P53 statistically was not significant with $\mathrm{p}$ value 0.1 because there is no obvious change in the expression between endometrial hyperplasia and carcinoma.

Table (5): P53 Expression in Endometrial Hyperplasia and Carcinoma

\begin{tabular}{ccccccc}
\hline \multicolumn{2}{c}{ Pathological Changes } & P53 Positive No. & $\begin{array}{c}\text { P53 Negative } \\
\text { No. }\end{array}$ & Total No. & $\begin{array}{c}\text { \% of Positive } \\
\text { cases }\end{array}$ & $P$-Value \\
\hline \multirow{2}{*}{$\begin{array}{l}\text { Endometrial } \\
\text { hyperplasia }\end{array}$} & Simple & 18 & 15 & 33 & $(54.5)$ \\
\cline { 2 - 6 } & Complex & 9 & 2 & 11 & $(81.8)$ \\
\cline { 2 - 6 } & Atypical & 6 & 2 & 8 & $(75)$ & $(77.5)$ \\
\hline Carcinoma & 38 & 11 & 49 & \\
\hline $\begin{array}{c}\text { Total cases of hyperplasia } \\
\text { and carcinoma }\end{array}$ & $\mathbf{7 1}$ & $\mathbf{3 0}$ & $\mathbf{1 0 1}$ & $\mathbf{7 0 . 2}$ \\
\hline
\end{tabular}

As clarified in table 6 P53 expression in grades of endometrial carcinoma in the total endometrial carcinoma from grade I to III; The $\mathrm{p}$ value 0.5 is not significant statistically which mean the degree of positivity is not changed when the grade of the endometrial carcinoma progress.

Table (6): P53 Expression in Grades of Endometrial Carcinoma

\begin{tabular}{cccccc}
\hline $\begin{array}{c}\text { Grade of } \\
\text { carcinoma }\end{array}$ & $\begin{array}{c}\text { P53 Positive } \\
\text { No. }\end{array}$ & $\begin{array}{c}\text { P53 Negative } \\
\text { No. }\end{array}$ & Total No. & \% of Positive cases & P-Value \\
\hline Grade I & 17 & 4 & 21 & $(80.9)$ & 0.5 \\
\hline Grade II & 17 & 7 & 24 & $(70.8)$ & $(100)$ \\
\hline Grade III & 4 & 0 & 4 & $\mathbf{7 7 . 6}$ \\
\hline Total & $\mathbf{3 8}$ & $\mathbf{1 1}$ & $\mathbf{4 9}$ & \\
\hline
\end{tabular}


Table 7: clarified the pattern of ER expression. and carcinoma is statistically significant with $p$ The difference of expression between hyperplasia value 0.001 .

Table (7): ER Expression in Endometrial Hyperplasia and Carcinoma

\begin{tabular}{|c|c|c|c|c|c|c|}
\hline \multicolumn{2}{|c|}{ Pathological Changes } & $\begin{array}{c}\text { ER Positive } \\
\text { No. }\end{array}$ & $\begin{array}{c}\text { ER Negative } \\
\text { No. }\end{array}$ & Total No. & $\%$ of Positive cases & $P$ value \\
\hline \multirow{3}{*}{$\begin{array}{l}\text { Endometrial } \\
\text { hyperplasia }\end{array}$} & Simple & 30 & 3 & 33 & $(90.9)$ & \multirow{4}{*}{0.001} \\
\hline & Complex & 8 & 3 & 11 & $(72.7)$ & \\
\hline & atypical & 6 & 2 & 8 & $(75.0)$ & \\
\hline Carcinoma & & 16 & 33 & 49 & $(32.6)$ & \\
\hline \multicolumn{6}{|c|}{ Total cases of hyperplasia and } & \\
\hline
\end{tabular}

Table 8 shows the expression of ER in carcinoma according to the grades. The $\mathrm{p}$ value was 0.7 and statistically was not significant which mean degree of expression of ER is not changed with the increase of the grades of the carcinoma.

Table (8): ER Expression in Grades of Endometrial Carcinoma

\begin{tabular}{cccccc}
\hline $\begin{array}{c}\text { Grade of } \\
\text { carcinoma }\end{array}$ & ER Positive No. & ER Negative No. & $\begin{array}{c}\text { Total } \\
\text { No. }\end{array}$ & \% of Positivity & P-Value \\
\hline Grade I & 8 & 13 & 21 & 38.1 & 0.7 \\
\hline Grade II & 7 & 17 & 24 & 20.1 & 25.0 \\
\hline Grade III & 1 & 3 & 4 & $\mathbf{3 2 . 6}$ \\
\hline Total & $\mathbf{1 6}$ & $\mathbf{3 3}$ & $\mathbf{4 9}$ & \\
\hline
\end{tabular}

Table 9 shows the relation between the degree of the tumor invasion and the expression of these three markers. Statistically the correlation was not significant ( $\mathrm{p}$ value 0.6 ) which means that the expression of these markers is not increased with increasing of the myometrial invasion.

Table (9): The Relationship between the Three Markers Expression (Her2/neu, P53 and ER) and the Stage of

\begin{tabular}{|c|c|c|c|c|c|c|c|c|}
\hline \multicolumn{9}{|c|}{ Carcinoma } \\
\hline \multirow[t]{2}{*}{ Myometrium invasion } & \multirow[t]{2}{*}{ NO. } & \multicolumn{2}{|c|}{ Her2/neu } & \multicolumn{2}{|c|}{ P53 } & \multicolumn{2}{|c|}{ ER } & \multirow[t]{2}{*}{$P$ value } \\
\hline & & +ve & $\%$ & +ve & $\%$ & +ve & $\%$ & \\
\hline T1a(No invasion) & 33 & 16 & $(78.7)$ & 26 & $(48.4)$ & 12 & $(36.3)$ & \multirow{4}{*}{0.9} \\
\hline $\mathrm{T} 1 \mathrm{~b}$ (Less than half) & 4 & 2 & $(75)$ & 3 & $(50)$ & 1 & $(25)$ & \\
\hline T1c(More than half) & 3 & 2 & $(100)$ & 3 & $(66.6)$ & 1 & $(33.3)$ & \\
\hline $\begin{array}{l}\text { T2-T3(Invasion outside of } \\
\text { the myometrium) }\end{array}$ & 9 & 3 & $(66.6)$ & 6 & (33.3) & 2 & $(22.2)$ & \\
\hline Total & 49 & 23 & $(77.5)$ & 32 & $(46.9)$ & 16 & $(32.6)$ & \\
\hline
\end{tabular}

Table 10 shows the number and percentage of cases progressed from hyperplasia to carcinoma. Among 49 cases of carcinoma, 6 cases that were initially diagnosed endometrial hyperplasia
$(2=18.2 \%$ and $4=50 \%$ cases were transmitted from complex without atypia and atypical hyperplasia respectively). 
Journal of University of Duhok, Vol. 22, No.1 (Pure and Eng. Sciences), Pp 132-147, 2019 https://doi.org/10.26682/sjuod.2019.22.1.15

Table (10): Endometrial Carcinoma Cases that Previously Diagnosed as Endometrial Hyperplasia

Type of hyperplasia

No.

No. of carcinoma cases that previously diagnosed as

$\%$ endometrial hyperplasia

\begin{tabular}{cccc}
\hline Simple & 33 & 0 & $(0)$ \\
\hline Complex & 11 & 2 & $(18.2)$ \\
\hline Atypical & 8 & 4 & $(50)$ \\
\hline Total & 52 & 6 & $(\mathbf{1 1 . 5 )}$ \\
\hline
\end{tabular}

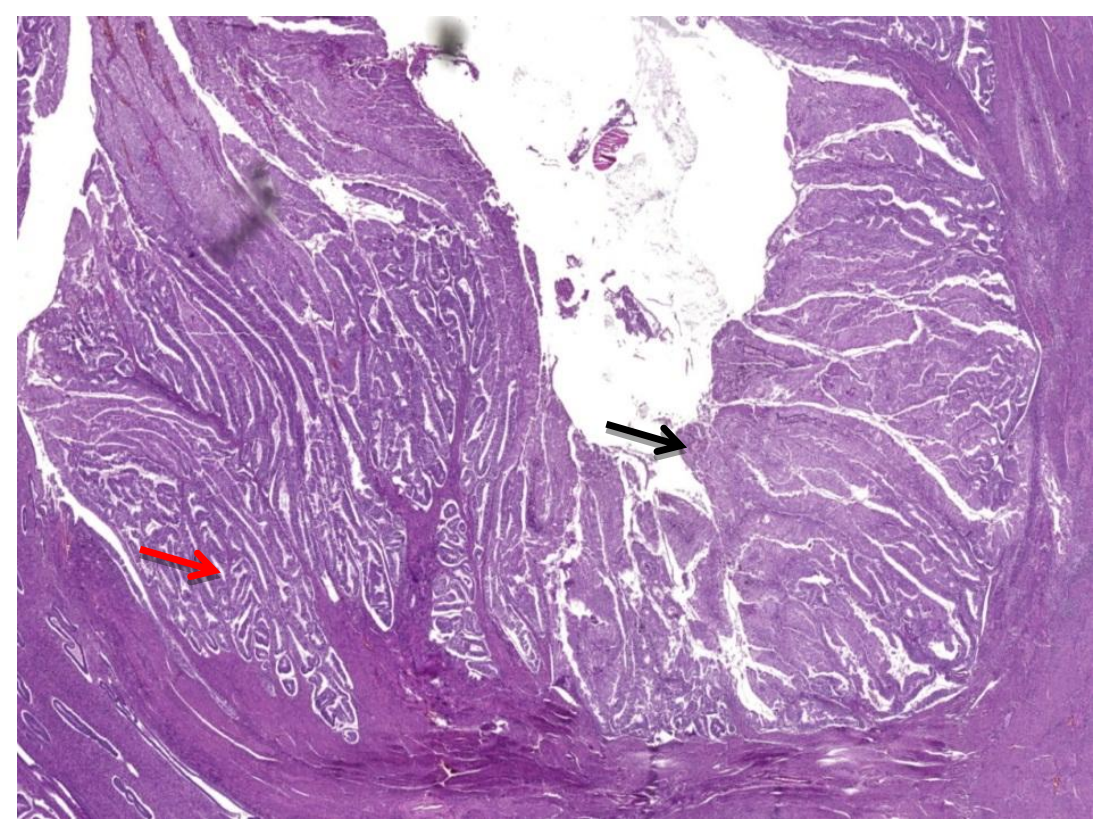

Fig. (4): Section of Endometrial Carcinoma (grade I), shows villoglandular pattern (black arrow). Note the back to back glands with absence of stroma (red arrow) $(\mathrm{H} \& \mathrm{E}, \times 40)$

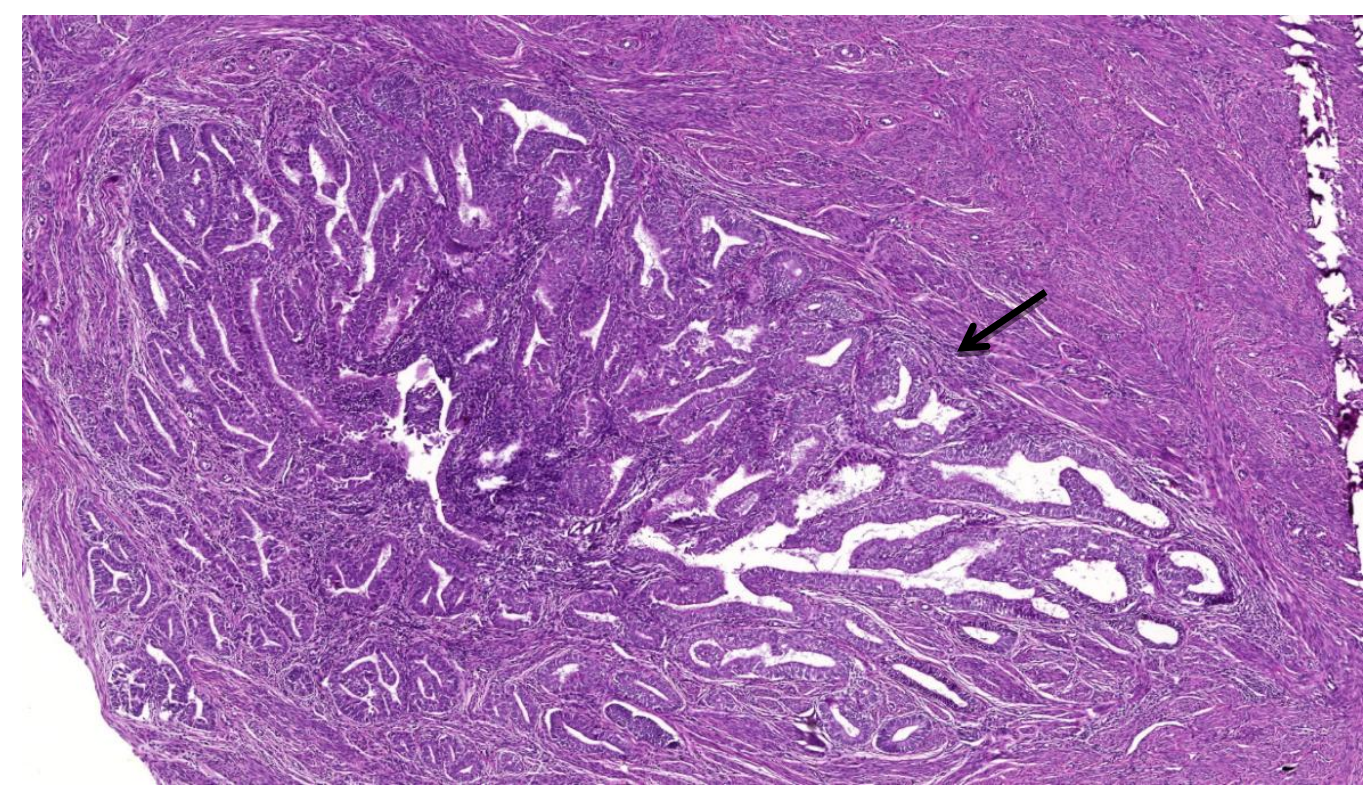


Fig. (5): Section of Endometrial Carcinoma (grade I). It shows glandular proliferation with back to back appearance and notes the myometrial invasion (black arrow) (H\&E, x100)

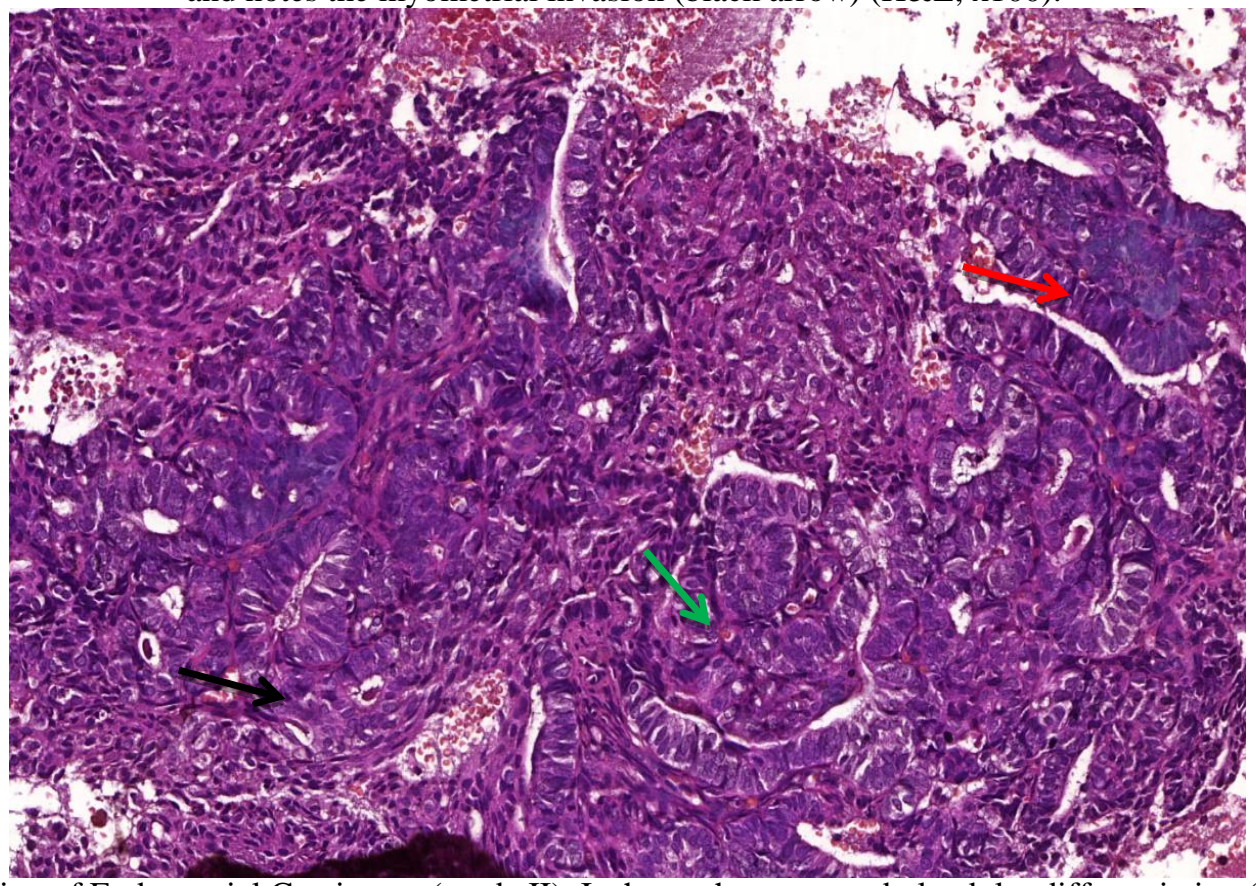

Fig. (6): Section of Endometrial Carcinoma (grade II). It shows the preserved glandular differentiation (black arrow) with an area of sheet of neoplastic cells (green arrow). There are dysplastic changes; hyperchromasia (red arrow), increased N/C ration and nuclear pleomorphism (H\&E, x400).

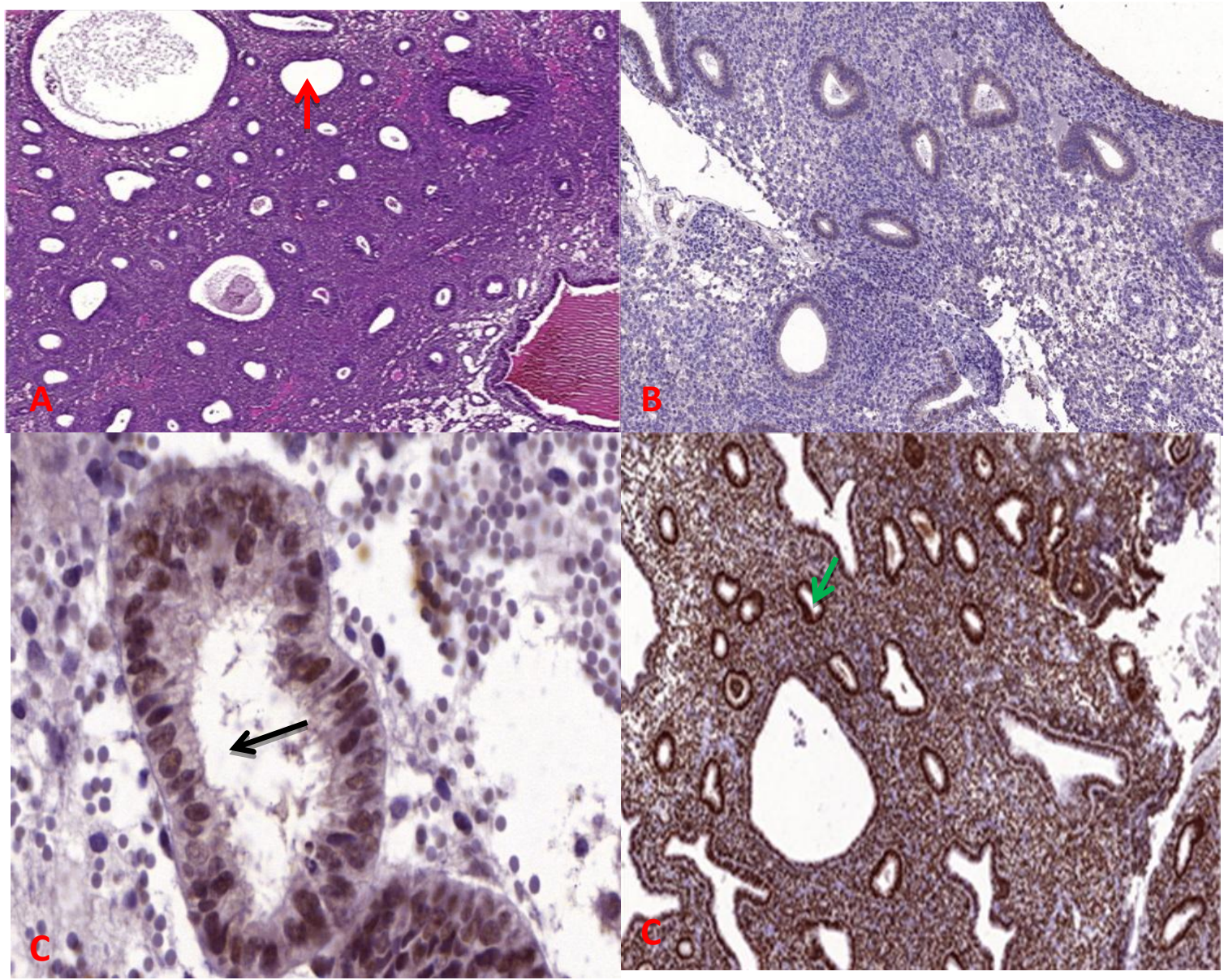


Fig 7: Simple Endometrial Hyperplasia. (A) Simple endometrial hyperplasia stain with H\&E ( x40) shows cystic dilatation (red arrow). (B) Negative staining for Her2/neu (x100). (C) P53 showing marked nuclear staining of the glandular epithelial cells (black arrow) (x400). (D) ER shows nuclear staining in stroma and glandular epithelial cells
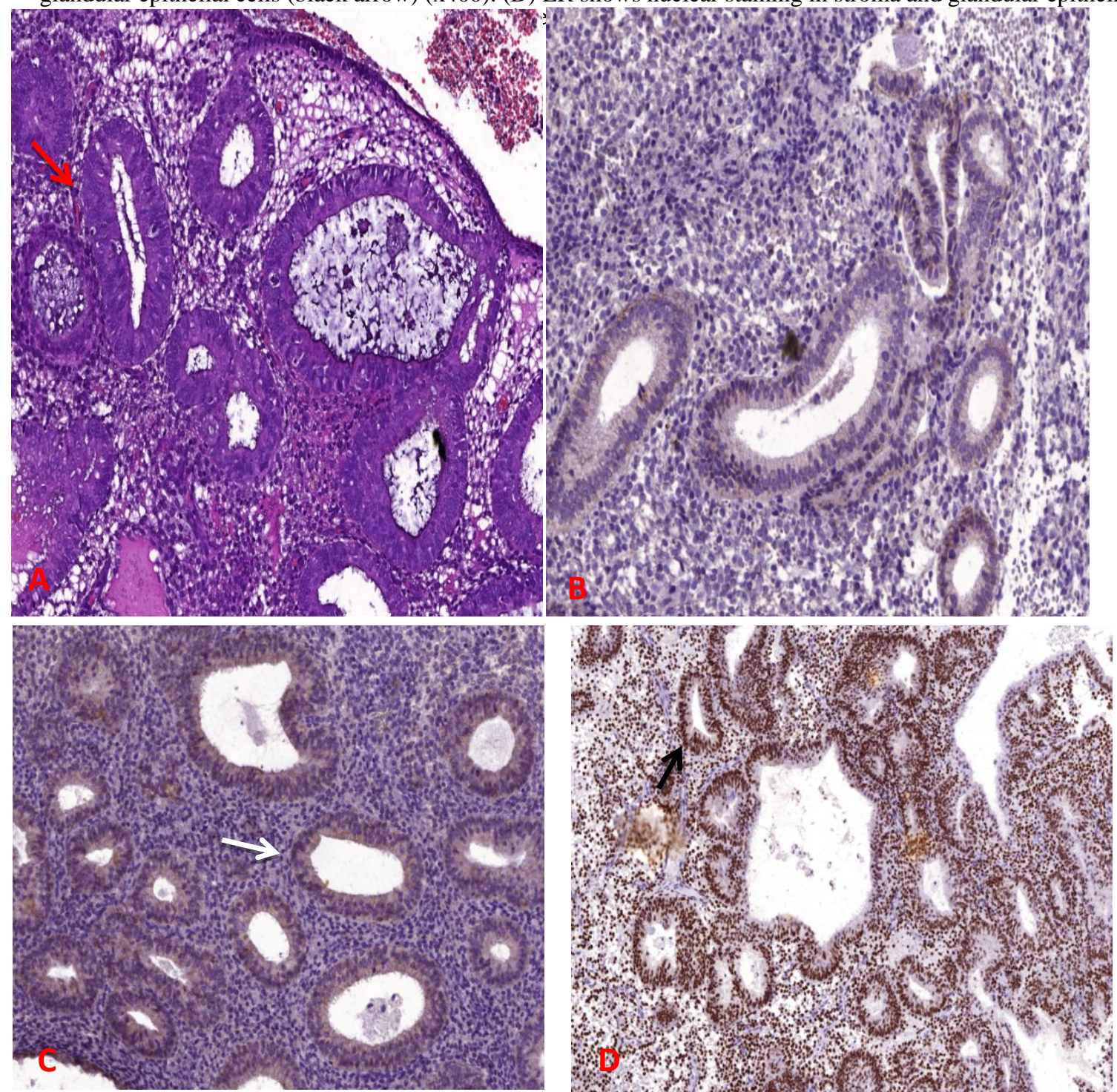

Fig. (8): Complex Endometrial Hyperplasia. (A) Complex glandular configurations, including multilayering, budding with increased a gland-to-stroma ratio. The glands are closely back to back with scant intervening stroma and highly irregular in size and shape (red arrow). The atypia is absent (H\&E x40). (B) Negative staining for Her2/neu. (C \& D) Immunoreactivity for P53 and ER (white and black arrows) (x400). 
Journal of University of Duhok, Vol. 22, No.1 (Pure and Eng. Sciences), Pp 132-147, 2019 https://doi.org/10.26682/sjuod.2019.22.1.15
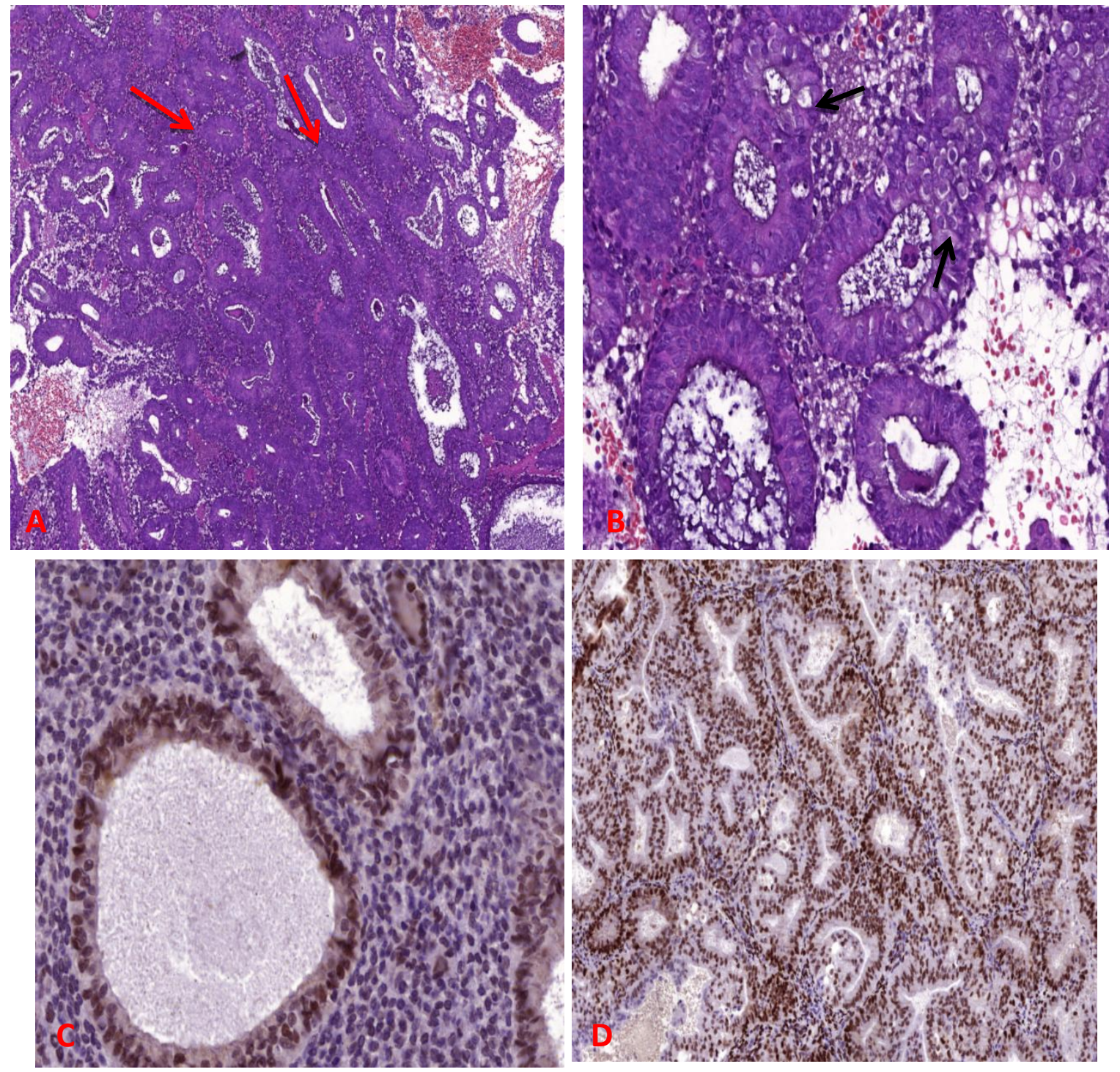

Fig. (9): Atypical Endometrial Hyperplasia (A \& B) Showing glandular crowding, multilayering of lining epithelium, hyperchromatic nuclei (red arrow) and note the mitoses (black arrows) (H\&E, x100). (C) P53: + (x400). (D) ER: + (x100) 

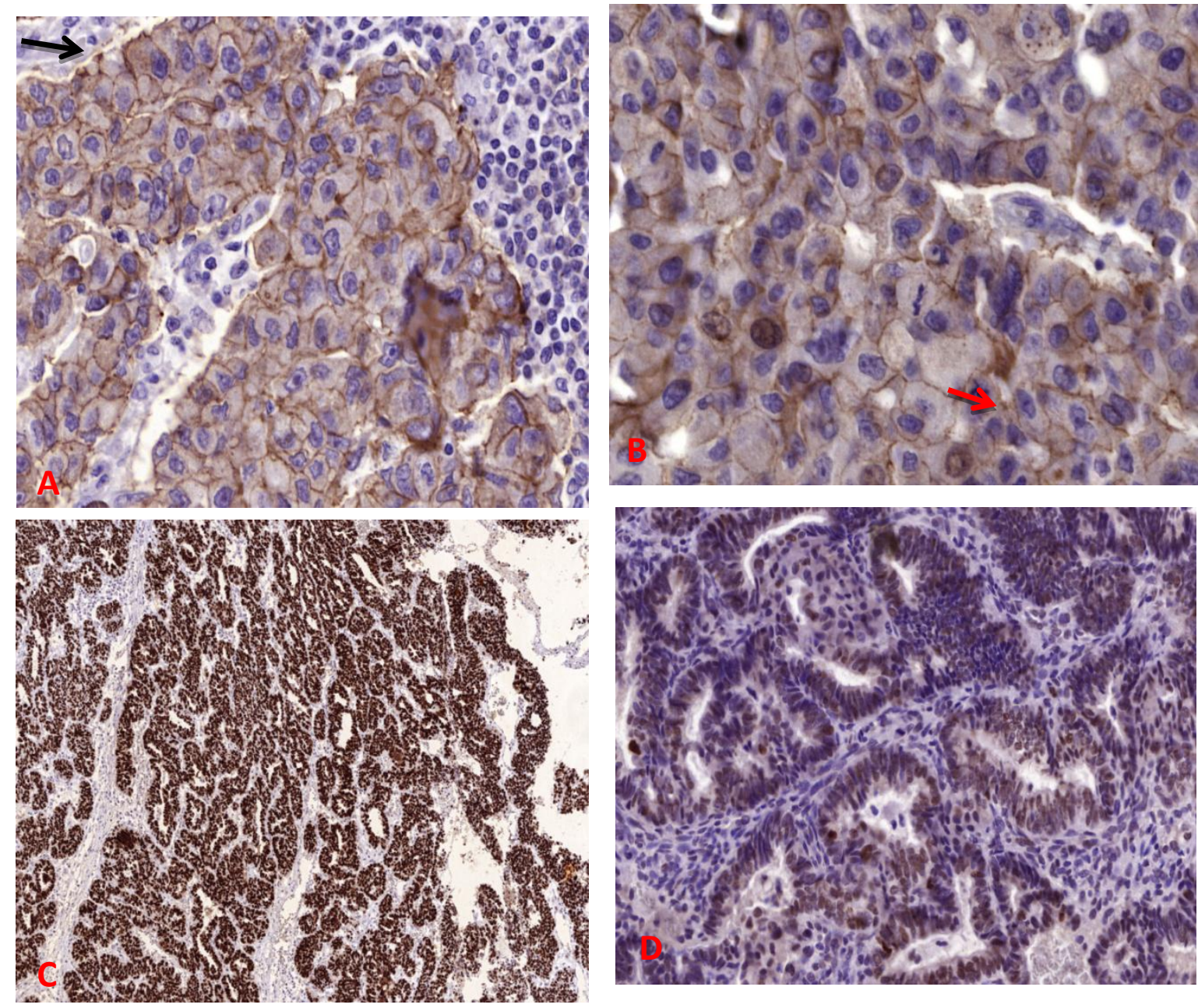

Fig.(10): Triple Markers Immunreactivity in Endometrial Carcinoma: (A \& B) show the membrane staining with Her2/neu (black arrow) (x400). (C) Shows the marked nuclear staining with P53 (x40). (D) Nuclear staining of ER (x100). Note the tripolar mitosis (red arrow).

\section{DISCUSSION}

In the current study, cases of endometrial hyperplasia incidence were more common in age interval (41-50) years and the second common age range was (51-60) years. A study done in Pakistan also showed that the most common age group of endometrial hyperplasia between (41-50 years) which is compatible with this study (Takreem et al., 2009).

The most common age range of endometrial carcinoma seen in this study was in age interval (51-60 years) and the next common age range group was (41-50 years), but another study in Iran (Maliheh et al., 2005) had shown that the most common age interval of endometrial carcinoma was (61-70) years. This difference raises the question about etiology and the management of hyperplasia and carcinoma in our locality.

The frequency of the simple endometrial hyperplasia in this study was $63.5 \%$, which is more than complex and atypical hyperplasia $(21.1 \%, 15.4 \%$ respectively) and this was also what found in another study done in India (95.6\% vs. 3.6\%,0.8\% respectively) (Gargi et al., 2013). The current study has shown that the simple hyperplasia with atypia was completely absent.

Regarding the carcinoma, grade II was the most frequent cases of endometrial carcinoma $(24 / 49=48.9 \%)$ with the mean age of 56.6 years, while the grade III was the least group $(4 / 49=8.2 \%)$ but with mean age 68.7 years. These results were different from another study done by 
(Goto et al., 2012) in Japan they found the mean age was 68 years of grade II group.

In the current study, overexpression of Her2/neu was observed in a relatively high percentage (44.9\%), another study correlates with the current findings where Her2/neu expression was found in about 45\% (Morrison et al., 2006). In regarding to the grade and the stage of tumor the correlation was statistically not significant, even though Her2/neu overexpression showed direct increase with the grade increasing. These findings were in contrast with another study done in Romania that showed the highest positivity was in grade II $84.6 \%$ (Ilyés et al., 2011).

In this study, the higher positivity of Her2/neu was seen in more invading tumor, the expression increased from $48.4 \%$ in non-invasive tumors, to $50 \%$ in less than half of myometrial thickness invasion and $66.6 \%$ in tumor invades more than half of the wall thickness. However, statistically was not significant. Results from similar study were in concordant with the current study (Srijaipracharoen et al., 2010) done in Germany, who found that the histologic stage and depth of invasion did not correlate with Her2/neu oncoprotein expression.

The present study showed higher expression of P53 in the complex (81.8\%) and atypical hyperplasia $(75 \%)$ than that found in simple hyperplasia (54.5\%). These findings are in agreement with (Ilie et al., 2011), A study done in Romania, who found that positivity to P53 belonged to complex hyperplasia (30\%), atypical hyperplasia endometria (60\%) and was absent in simple hyperplasia. Also the overexpression of P53 was observed in endometrial carcinoma with percentage $(77.5 \%)$. Results found by (Ragni et al., 2005) were correlate with this present study; they found P53 overexpression is $61 \%$ of the studied cases. These findings indicate the correlation between mutant P53 gene and appearance of carcinoma.

The correlation between P53 expression and the grades of tumor was not significant; P53 overexpression showed lowest positivity in grade II reaching $70.8 \%$, while grade III show full positivity $100 \%$ and $80.9 \%$ in grade I. These findings were incompatible with a study done in Erbil that showed the highest positivity was on grade II 69.2\% (Ahmed and Isaac, 2010).

P53 expression was observed in $100 \%$ when there was a deep myometrial invasion and $78.7 \%$ in the superficial myometrial invasion. These results highlight the importance of P53 detection in endometrial carcinoma as an indicator for progression of disease. These results are disagree with those obtained by ((Erdem et al., 2003) in Norway.

The present study reported that ER immunoreactivity was higher in simple and lower in complex and atypical hyperplasia (90.9\% vs. 72.7 and $75 \%$ respectively). These findings are in contrast with (Bozdoğan et al., 2002) study done in Turkey, who reported that ER are frequently more often positive in non-atypical endometrial hyperplasia when compared to atypical hyperplasia. while ER expression was observed in endometrial carcinoma with low percentage (32.6\%). Another study correlates with the present findings; they found that the expression of ER was 48\% (Aparna et al., 2009). While these findings are lower than the frequency observed in Germany by (Pieczyńska et al., 2011) who found that ER was positive in $71 \%$ of studied cases.

In spite of non-significant correlation between ER expression with grade and stage of carcinoma, but this study has shown that the frequency of the ER is decrease when the grade is developed from grade I $(38.1 \%)$ to grade III $(25 \%)$. A study done in Japan found the same relationship; grade I tumors are more frequently positive for the estrogen receptors than the grade III endometrial carcinoma (Uchikaw et al., 2003). Also, the frequency of positivity was decreased with the myometrial invasion. It was $36.3 \%$ in cases with no myometrial invasion then decreased to $33.3 \%$ in deep invasion. These results are disagrees with that obtained by (Cai et al., 2008) in Japan, who found that the positivity increased with the myometrial invasion from $47.6 \%$ to $50.9 \%$.

The comparison between the expression of ER and Her2/neu in hyperplasia and carcinoma showed converse relationship, most of the cases showed disparity in their expressions $(63.3 \%$ in endometrial hyperplasia and $51 \%$ in endometrial carcinoma).

The hyperplasia was known to be complicated by carcinoma, in the current study 6 cases previously diagnosed hyperplasia were progressed towards carcinoma later on. This includes $18.2 \%$ and 50\% from complex and atypical hyperplasia respectively. The same results were found in a study done in United State by (Lacey and Chia, 2009) who found that $13 \%$ of complex cases and 
$50 \%$ of atypical case were progressed to carcinoma.

\section{CONCLUSION}

SHer2/neu showed a significant expression in the endometrial hyperplasia and endometrial carcinoma. These results assumed that Her2/neu plays an important role in the pathogenesis of endometrial carcinoma and therapies directed against Her2/neu. Although, statistically was not significant, there was a concordance between Her2/neu expression with increasing grade and increasing in the depth of myometrial invasion. Expression of ER was markedly decreased while the disease progress forms simple, complex, atypical hyperplasia towards endometrial carcinoma. These decreasing data of ER expression may serve it as a marker of endometrial carcinogenesis and diagnostic measure. Expression of P53 showed no significant changes between endometrial hyperplasia and carcinoma. Although the correlation between expression of P53, grade and depth of myometrial invasion was also not significant but it gave full immunoreactivity in cases with high grade and in highly invasive tumor. The expressions of these three markers (Her2/neu, P53 and ER) were independent and they showed a converse relationship especially between Her2/neu and ER. The expression pattern of these markers is highlighting the probability of multi-step theory of carcinogenesis in endometrial carcinoma resembling other cancers.

\section{REFERENCES}

Ahmed N, Isaac R (2010). P53 Expression in Endometrial Hyperplasia and Endometrial Carcinoma. Zanco Journal of Medical Science; 14 (2):28-34.

- Al-Bader Maie, Ford Christopher, Al-Ayadhy Bushra, Francis Issam (2011). Analysis of estrogen receptor isoforms and variants in breast cancer cell lines. Experimental and Therapeutic; 2 (3):537-544.

- Aparna A, Donna C, William M et al. (2009). EphA2 overexpression is associated with lack of hormone receptor expression and poor outcome in endometrial cancer. Cancer; 115(12): 2684-2692.

- Bozdoğan Ö, Atasoy P, Erekul S et al. (2002). Apoptosis-Related Proteins and Steroid Hormone Receptors in Normal, Hyperplastic, and Neoplastic Endometrium. International Journal of Gynecological Pathology; 21(4): 375-382.
- Cai H, Yun-feng Z, Bi-cheng W, Ling-ling G (2008). Expression of estrogen receptors and protein in endometrial carcinoma. Cancer Therapy; 6: 907-912.

- Catasús L, Gallardo A, Cuatrecasas M Prat J (2009). Concomitant PI3K-AKT and p53 alterations in endometrial carcinomas are associated with poor prognosis. Modern Pathology; 22(4):522-529.

- Erdem O, Erdem M, Dursun A et al. (2003). Angiogenesis, p53, and bcl-2 expression as prognostic indicators in endometrial cancer: Comparison with traditional clinicopathologic variables. International Journal of Gynecological Pathology; 22(3):254-260

- Galic Vijaya, Schiavone Maria, Herzog Thomas, Holcomb Kevin et al. (2013). Prognostic Significance of Mucinous Differentiation of Endometrioid Adenocarcinoma of the Endometrium. Cancer Investigation; 31(7):500-508.

- Gargi R (2013). Endometrial Hyperplasia: A Clinicopathological Study in a Tertiary Care Hospital. The Journal of Obstetrics and Gynecology of India; 63(6): 394-398.

- Goto T, Takano M, Aoyama T et al. (2012). Prognosis of high-grade endometrial cancer: a comparison of serous-type and clear cell type to grade 3 endometrioid-types. European Journal of Gynecological Oncology; 33(6):579-583.

- Ilie D, Georgescu CV, Simionescu C (2011): "Immunohistochemical Aspects of Endometrium Hyperplasia in Perimenopause". Current Health Sciences Journal; 37(2):20-67.

- Ilyés L, Rădulescu C, Grama O et al. (2011) Overexpression of HER2/neu Receptor-Prognostic Factor in Endometrial Cancer. Acta medicine marissiensis; 57(5):55-62.

- Kumar V, Cotran S, Robbins L (2003). Robbins basic pathology- $7^{\text {th }}$ edition. Philadelphia: Saunders. 691694.

- Lacey J V, Ioffe Jr, B M Ronnett, B Rush et al. (2008). Endometrial carcinoma risk among women diagnosed with endometrial hyperplasia: the 34-year experience in a large health plan. British Journal of Cancer; 98: 45-53.

- Lacey J, Chia M (2009). Endometrial hyperplasia and the risk of progression to carcinoma. Maturitas; 63(1):39-44.

- Maliheh A, Giti N, Seyyedeh K (2014). Comparison of Crude and Age-Specific Incidence Rates of Breast, Ovary, Endometrium and Cervix Cancers in Iran, 2005. Asian Pacific Journal of Cancer Prevention; 15 (6): 2461-2464.

- Mariani Andrea, Sebo Thomas, Katzmanna Jerry et al. (2005). HER-2/neu Overexpression and Hormone Dependency in Endometrial Cancer: Analysis of Cohort and Review of Literature. ANTICANCER RESEARCH ; 25: 2921-2928. 
- Morrison C, Cohn DE, Zanagnolo V et al. (2006). HER-2 is an independent prognostic factor in endometrial cancer: association with outcome in a large cohort of surgically staged patients. Journal of Clinical Oncology; 24(15):2376-2385.

- Okuda Tsuyoshi, Sekizawa Akihiko, Purwosunu Yuditiya et al. (2010). Genetics of Endometrial Cancers. Obstetrics and Gynecology International; 13: 3-8.

- Osz J, Yann B, Carole P et al. (2012). Structural basis for a molecular allosteric control mechanism of cofactor binding to nuclear receptors. Proceeding of the National Academy of Science; 109(10): 588-594.

- Pieczyńska B, Szymon W, Anton Ż et al. (2011). Analysis of PTEN, estrogen receptor $\alpha$ and progesterone receptor expression in endometrial hyperplasia using tissue microarray. Polish Journal of Pathology; 3: 133-138.

- Ragni N, Simone F, Federico P et al. (2005). The association between p53 expression, stage and histological features in endometrial cancer. European Journal of Obstetrics, Gynecology and Reproductive Biology; 123(1): 111-116.

- Srijaipracharoen S, Tangjitgamol S, Tanvanich S, Manusirivithaya S et al. (2010). Expression of ER, PR, and Her-2/neu in endometrial cancer: a clinicopathological study. Asian Pacific Journal of Cancer Prevention; 11(1):215-20.

- Takreem A, Nargis D, Sadia R (2009). Incidence of endometrial hyperplasia in 100 cases presenting with polymenorrhagia in premenopausal women. Journal of Ayub Medical College, Abbottabad; 21(2):60-63

- Uchikaw J, Tanri S, Hsien-Chang S et al. (2003). Expression of steroid receptor coactivators and corepressors in human endometrial hyperplasia and carcinoma with relevance to steroid receptors and $\mathrm{Ki}$ 67. Cancer expression; 98(10):2207-2213.

- Vogelstein B, Lane D, Levine A (2000). Surfing the p53 network. Nature; 408: 307-310.

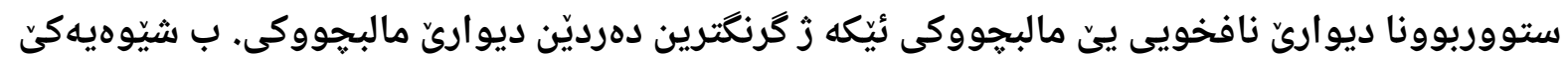

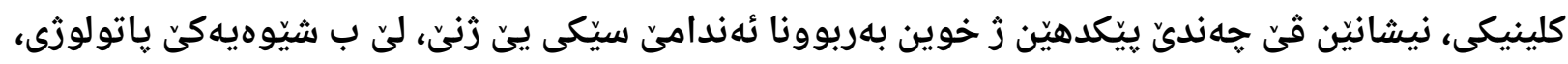

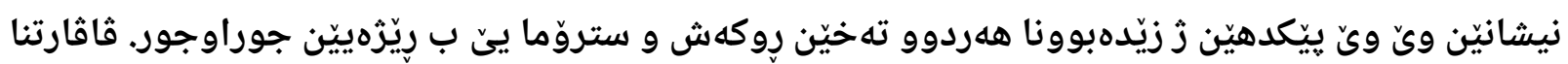

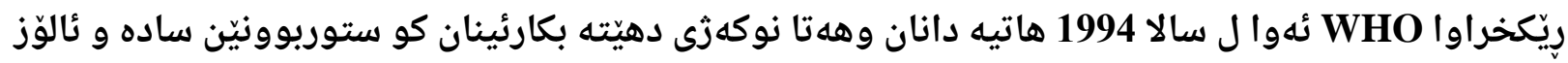

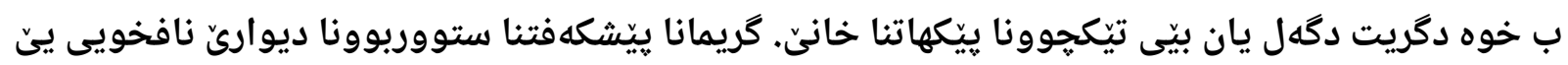

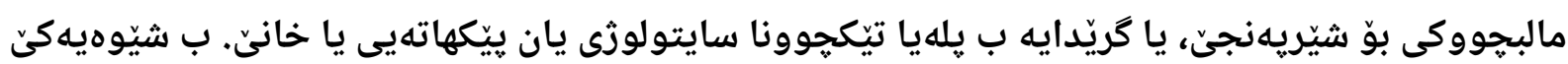

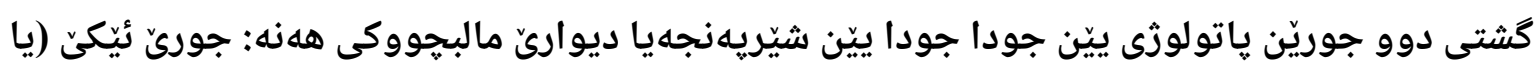

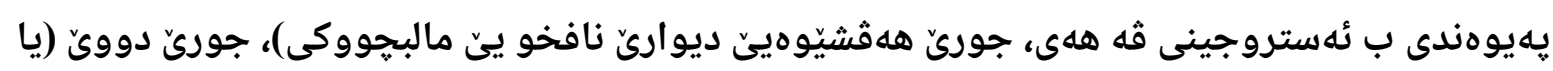

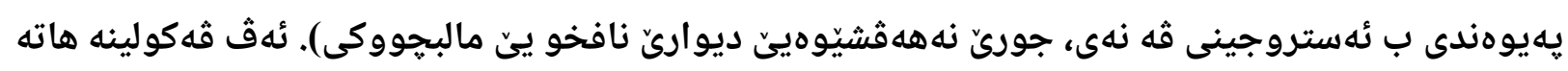

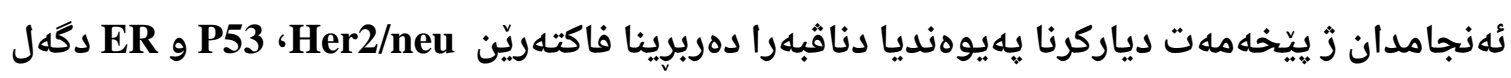

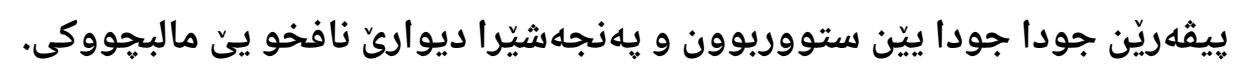
كهرهسته و ريّكين كارى:

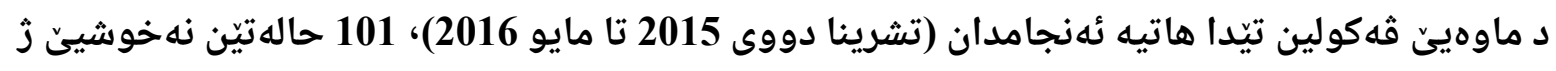

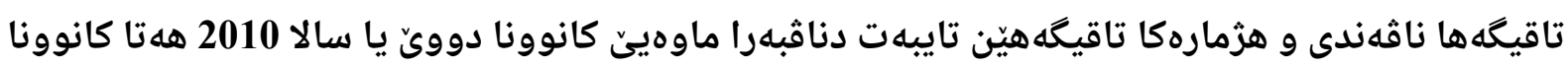

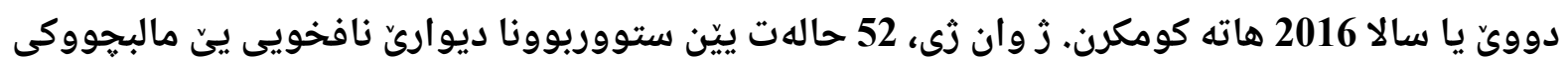

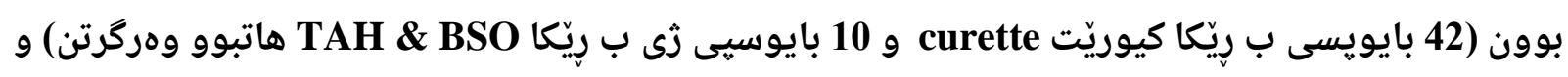


49 حاله تيّن دى زى يِين يهنجهشيّرا ديواري نافخويى يـ مالبجووكى بوون (ههمى بايويسى ب ريّيكا TAH

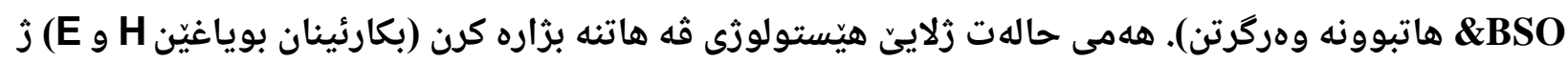

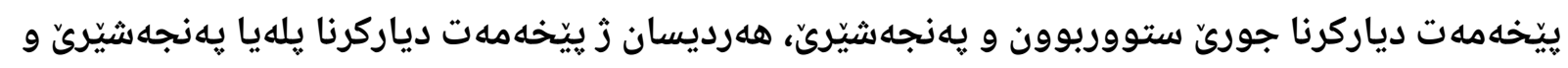
يلهيا قه كرتنا زهمله كيّن ديواريّ مالبجووكى. سى ماركهر هاتنه بكارئينان (

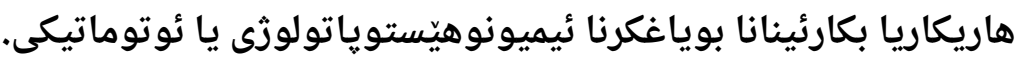

ئهنجام:

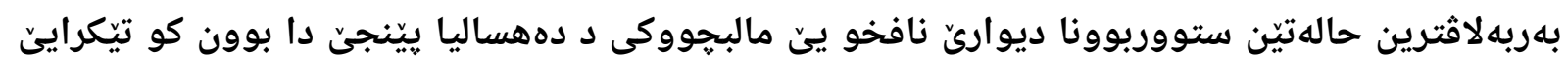

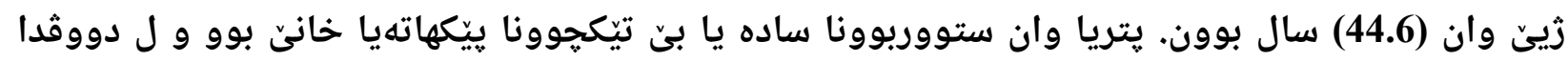

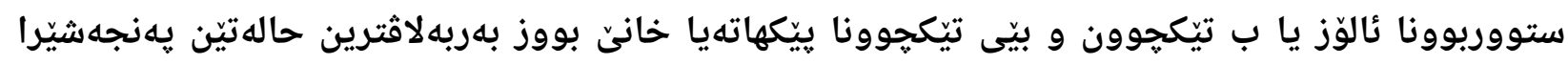

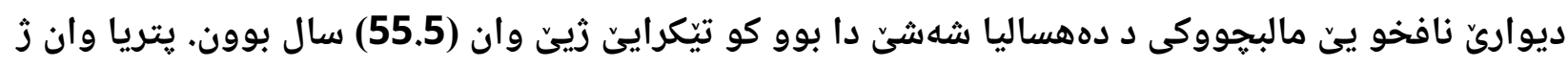

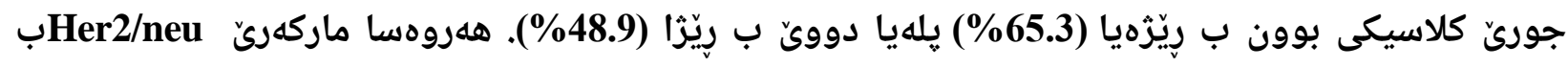

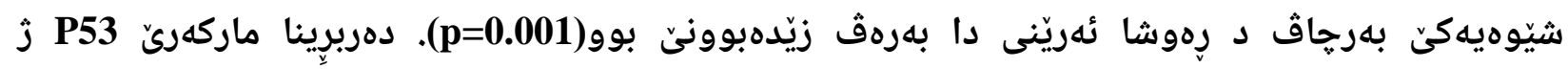

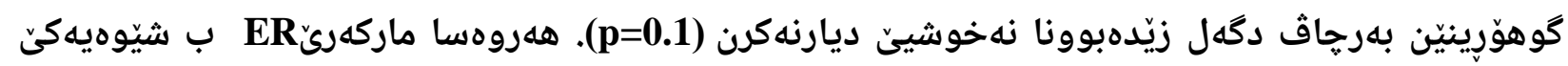

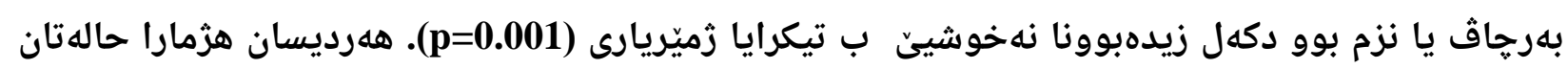

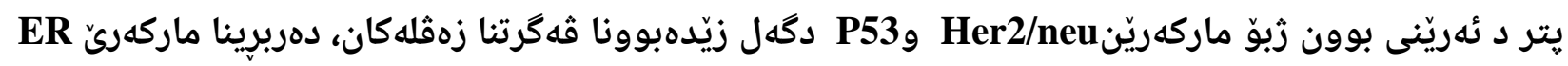

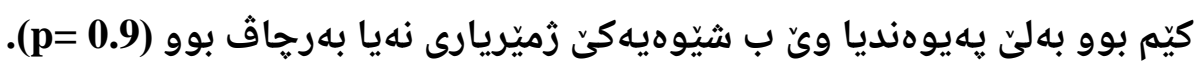

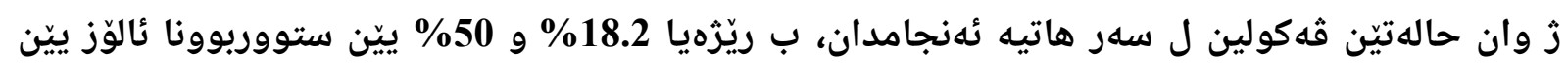

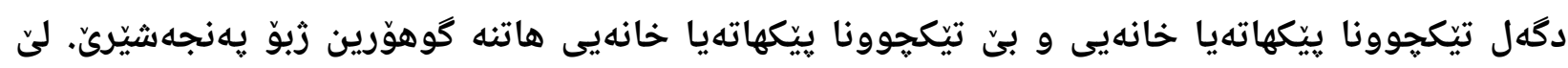

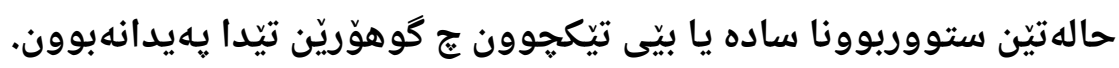
دهرئهنجام:

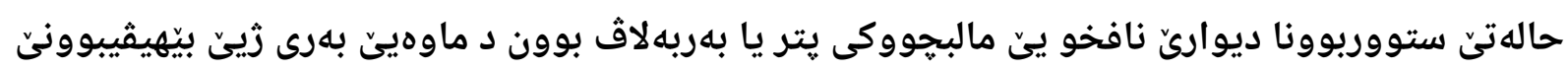

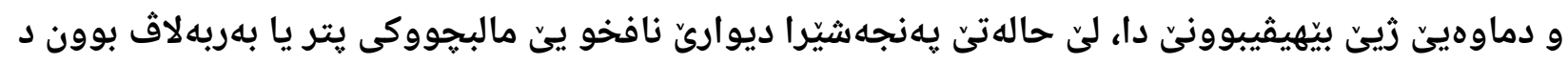

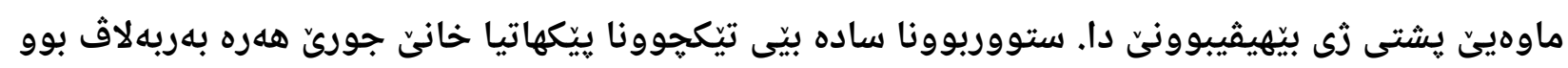

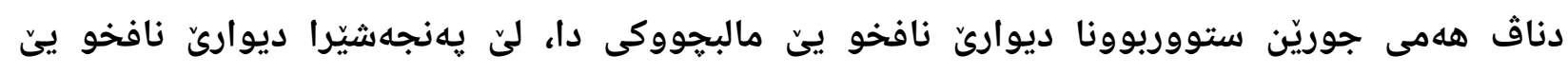

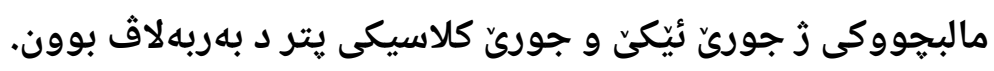

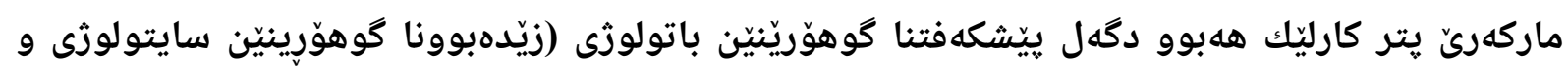

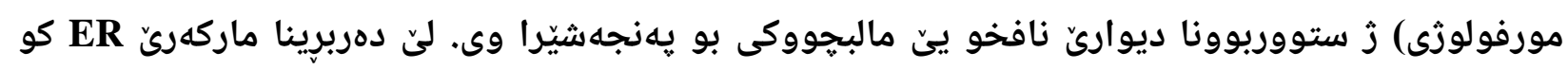

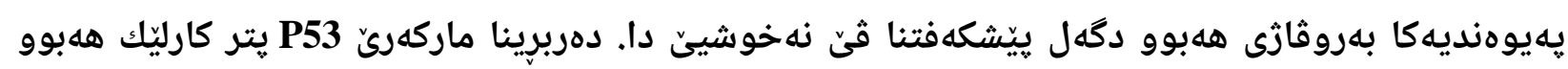

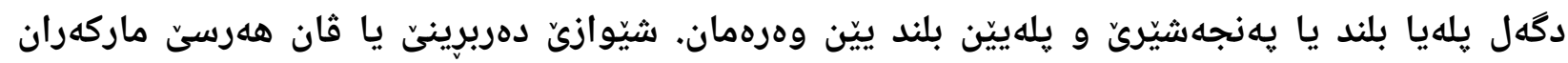

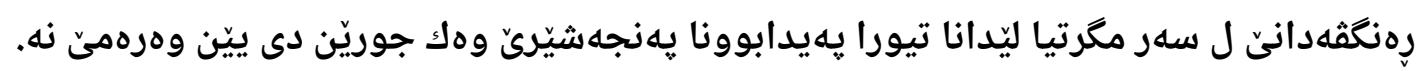


يعتبر تضخم بطانة الرحم واحد من أهم افات جدار الرحم الداخلي, الذي يتصف سريريا بنزيف مهبلي

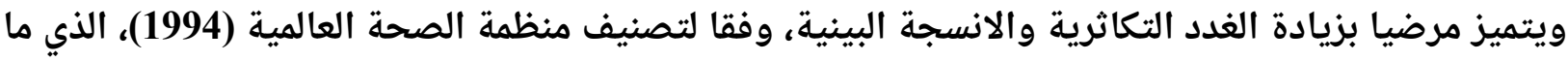

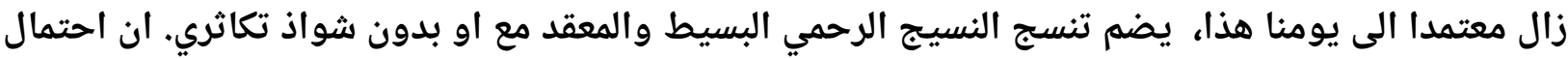

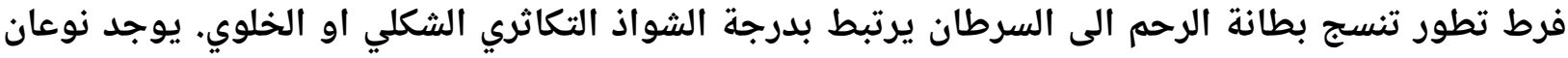

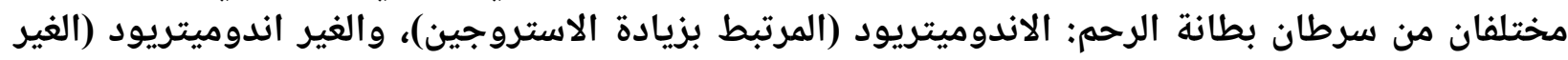
مرتبط بزيادة الاستروجين).

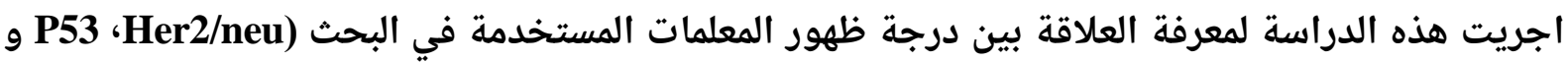

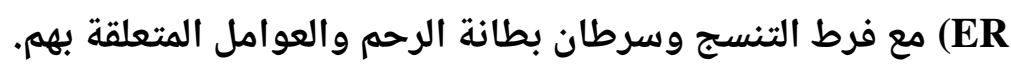

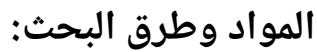

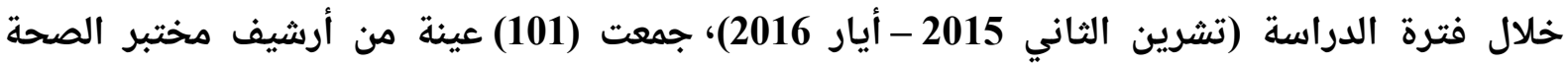
المركزي وبعض المختبرات الخاصة، من ضمن الكتل المأخوذة (كانون الثران الثاني 2012 - كانون الثاني الثاني 2016)،

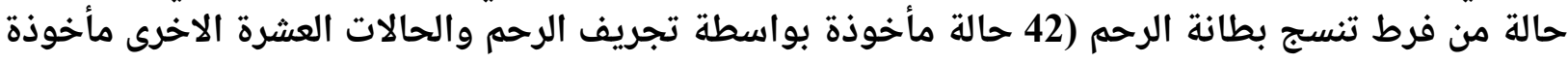
بعد اجراء عملية رفع الرحم كاملا), و(49) حالة من سرطان بطانة الرحانة الرحم (تم الحصول عليها من رفع الكامل

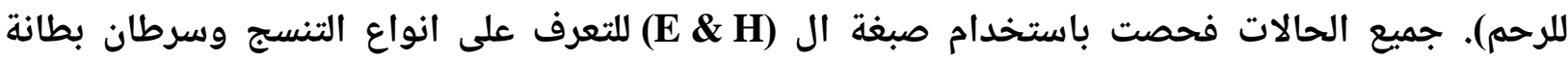
الرحم، وكذلك درجة غزو الورم داخل جدار الرحم. وباستخدام التلوين الالي تم تلوين جميع العينات بالمعلمات

(ER و P53, Her2/neu)

النتائج:

اظهرت النتائج ان معظم حالات فرط تنسج بطانة الرحم كانت من نوع التضخم البسيط دون شواذ النّان تكاثري

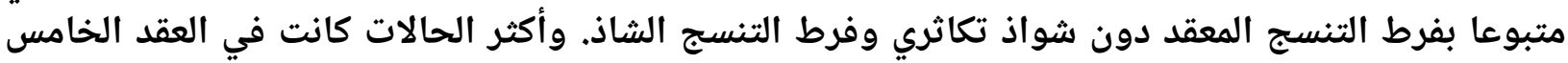

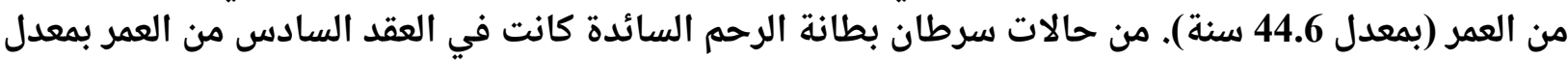

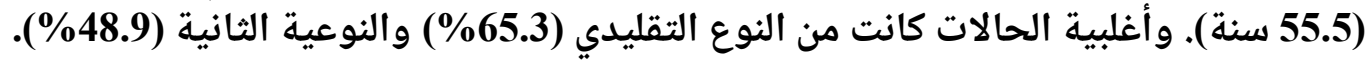

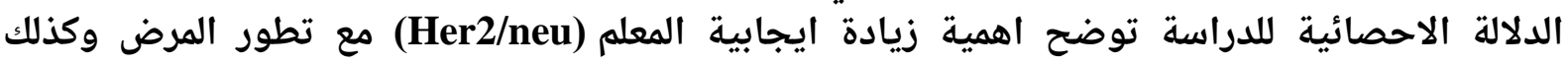

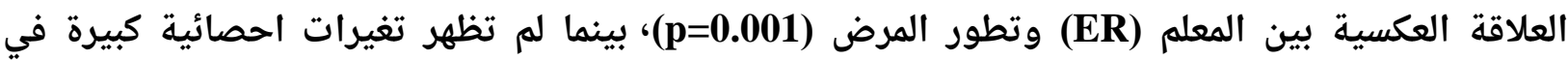

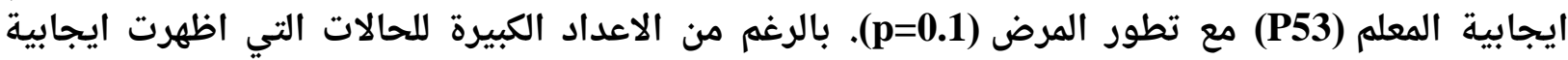

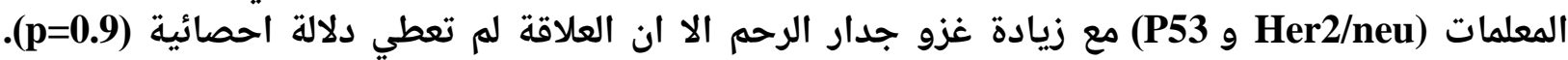

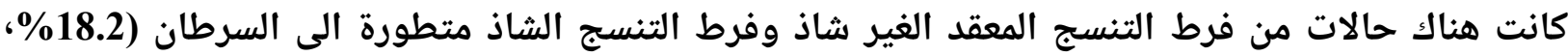

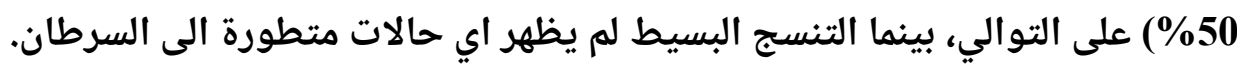

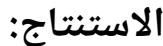
حالات فرط تنسج بطانة الرحم كانت الاكثر انتشارا في الفترة ما قبل سن اليأس، بينما سرطان بطانة

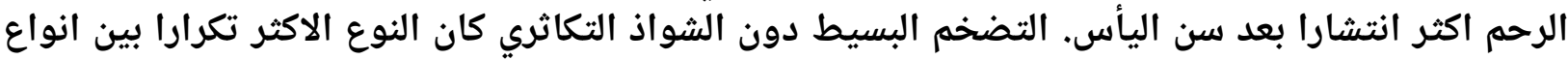

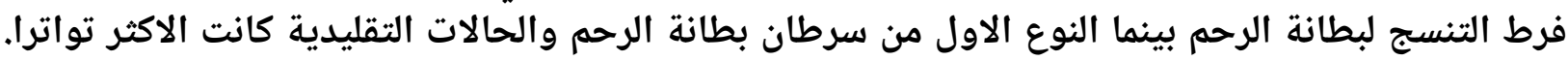

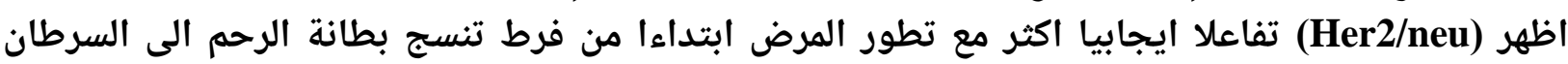


خلافا لتفاعل المعلم (ER) والذي اظهر العلاقة العكسية مع تطور المرض. اظهرت الدراسة ان (P53) اكثر

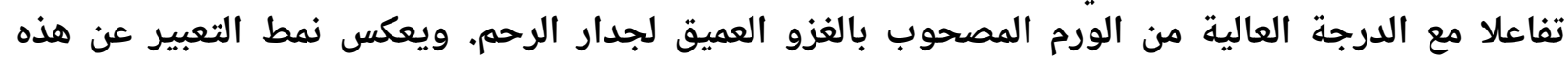

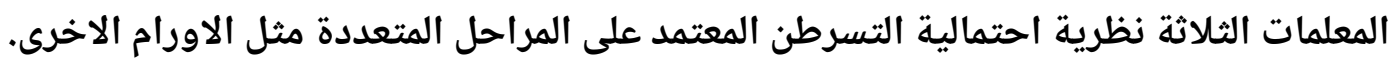

